\title{
Influence of air tightness of the building on its energy-efficiency in single-family buildings in Poland
}

\author{
Artur Miszczuk ${ }^{1, *}$ \\ ${ }^{1}$ Warsaw University of Technology, Faculty of Civil Engineering, Institute of Civil Engineering, \\ Team Building and Sustainable Development Al. Armii Ludowej 16, 00-637 Warsaw, Poland
}

\begin{abstract}
This publication focuses on assessing the impact of the tightness of single-family houses with a higher energy standard on their energy demand for heating. To formulate conclusions quantitative and qualitative research, including tightness test (blower door) has been conducted in energy-efficient and passive houses. In the next step, energy demand for heating has been estimated. Based on the observation and results, the simulation of the impact of reducing the flow of infiltrated air through leaks in the buildings for energy demand for heating is calculated. The simulation results confirm the dependence between the tightness of the building and energy demand.
\end{abstract}

\section{Introduction}

In the revised Regulation of the Minister of Transport, Construction and Maritime Economy in 2013 (on the technical conditions to be met by buildings and their location) [1], a program of gradual reduction of energy consumption by new buildings was introduced. Achievement of the energy standard of the building at the design stage is in many cases impossible to meet because of the low air-tightness of the external partitions. This problem occurs in energy-efficient buildings where mechanical ventilation with heat recovery is used. The use of recuperation is a solution that largely limits the heat loss to the heating of the ventilation air. In this situation, the heat loss caused by the infiltration of the outside air is acquired.

\section{Examples of conventional tests and analyses on European market}

Croatian [2] and Lithuanian [3] researchers analysed the possibility of a relationship between the airtightness of a building and its demand for energy. They came up with the assumption that the building's airtightness is a factor influencing the speed of air infiltration. Consequently, it also affects the air quality in the building and ventilation,

* Corresponding author: a.miszczuk@il.pw.edu.pl 
but also the energy required for heating and/or cooling. The authors in them analyses prove that as the building's airtightness increases, heat losses decrease [4].

Analogical to Croatian and Lithuanian studies were conducted under Polish conditions $[5,6]$. The obtained results confirm the effect of leakage on the value of the demand for utility energy, and consequently, on the value of the demand for non-renewable primary energy. This impact is greater for buildings with lower energy requirements and for buildings with significant leaks.

In the conclusion of other studies in Poland worth recalling [7], the researcher has shown that low leakage of partitions may increase the demand for utility energy for heating and ventilation of energy-efficient buildings by up to $40 \%$.

\section{Required level of tightness for new buildings}

The Polish Technical Conditions (WT) [1] define the level of recommended airtightness of the building, which is respectively for the building:

- with gravitational ventilation $-\mathrm{n}_{50}<3.0 \mathrm{~h}^{-1}$ (where $\mathrm{n}_{50}$ is the number of air exchanges in a building, within $1 \mathrm{~h}$, by infiltration, at a pressure difference of $50 \mathrm{~Pa}$ )

- equipped with mechanical ventilation or air conditioning $-\mathrm{n}_{50}<1.5 \mathrm{~h}^{-1}$.

In the provisions the legislator recommends conducting a leak test after completion of construction. Replacing in WT the word "required" with the word "recommended" causes the record to become dead and the clear majority of investors do not conduct the examination.

In Poland, there is a provision requiring a leakage test, but this regulation was only applied to buildings that were submitted to the energy and passive buildings subsidy program (National Fund for Environmental Protection and Water Management NFOŚiGW [9]). In the case of applying for a grant, the building must meet several requirements specified by NFOŚiGW. One of the most important is to achieve the airtightness of the outer partitions at a relatively low level. Limit values depend on the building standard: for NF40 the airtightness should be no worse than $\mathrm{n}_{50} \leq 1.0 \mathrm{~h}^{-1}$ and for NF15 $\mathrm{n}_{50} \leq 0.6 \mathrm{~h}^{-1}$ (where NF is the demand for utility energy for heating and ventilation respectively: at $40 \mathrm{kWh} /\left(\mathrm{m}^{2} \cdot \mathrm{a}\right)$ and $\left.15 \mathrm{kWh} /\left(\mathrm{m}^{2} \cdot \mathrm{a}\right)\right)$ [9].

\section{Research}

To conclude whether there is a relationship between the building's airtightness level and its energy demand, energy-efficient and passive buildings located in different regions of Poland were tested.

\subsection{Assumptions for research}

17 single-family buildings located in the most diverse climates zone in Poland [10], which were characterized by potentially low energy requirements, were qualified for the study. The selection of buildings for energy consumption was based on:

- Energy Performance Certificate (if the building has one),

- grants application send by the building owner to NFOŚiGW for subsidies to the energy efficient building (NF40) or passive (NF15),

- preliminary analysis of the structure of the building.

All the buildings qualified for the test were equipped with mechanical ventilation with heat recovery from the air removed. 


\subsection{Research procedure}

Determination of the leakage level of individual buildings has been carried out in accordance with the applicable European Standard PN-EN ISO 9972:2015 [7], per method B. During the tests, all deliberately made openings in the building's enclosure (such as exterior doors, windows, chimney openings) and diffusers and ventilators in the ventilation system are closed or blinded [4]. Preparation of the building for the test also included the possibility of equalizing the air pressure by leaving all internal doors open in the heated zone of the building [5].

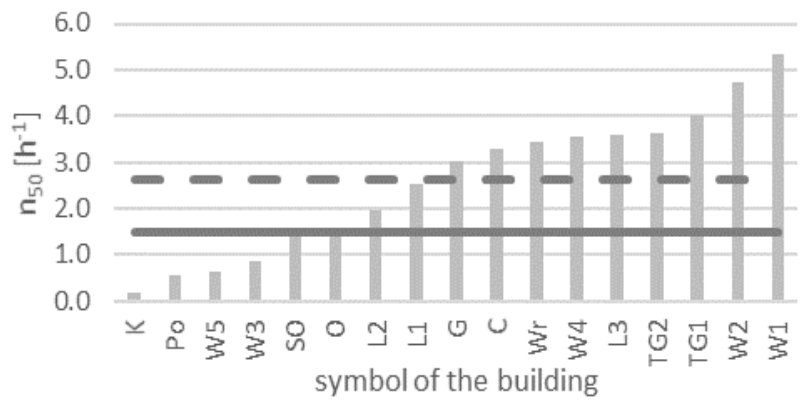

Fig. 1. Level of building's airtightness

The buildings in which the leakage test was carried out had a varying level of $n_{50}$ (from $0.17 \mathrm{~h}^{-1}$ for building $\mathrm{K}$ to $5.33 \mathrm{~h}^{-1}$ for $\mathrm{W} 1$ ) (fig. 1). Most of them exceeded the ventilation recommended for buildings with air infiltration value $\left(\mathrm{n}_{50}<1.5 \mathrm{~h}^{-1}\right)$ [1] (continuous line in Fig. 1). The average value for all buildings was $n_{50}=2.6 \mathrm{~h}^{-1}$ (dotted line in Fig. 1), and it exceeds (less than 2 times) the value of the infiltration.

\subsection{Calculation results}

The calculation of the energy demand for heating and ventilation (EU) was carried out using the monthly method in accordance with PN-EN ISO 13790 [11].

The most important data on which the calculation of the EU index is based are:

- surface, construction and materials used in the building's external walls,

- the type and characteristics of window and door joinery and how it is assembled,

- level of recuperation (recovery of heat from removed air).

The above listed parameters were obtained from projects, inventories and from designers, manufacturers of materials/equipment and/or owners/developers of buildings.

The necessary meteorological data were read out for the nearest metrological station located in the building. The most important weather data obtained from the Ministry of Infrastructure and Development [12] include:

- average monthly outdoor air temperature,

- the sum of the total solar radiation intensity on the N, E, S, W orientation.

Shading elements (such as neighbouring buildings, arcades) have been included in the calculations to reduce the amount of solar heat gain.

Based on the research, calculations and analyses, the most important parameters characterizing each of the examined buildings were determined. The most important properties include:

- heated surface of the building (table 1),

- outer baffle surface,

- the area of windows and glazing, 
- volume of heated part of the building,

- building shape factor (A/V, where A- is the surface of the building's external partition, V- building volume) (Table 1),

- heat transfer coefficients of the external partitions - walls, roofs, flooring and exterior windows and doors, the weighted average value of the heat transfer coefficient for all external partitions (walls, floors, roofs and windows and doors) - $\mathrm{U}_{\text {avg. }}$ (Table 1),

- the orientation of glazing to the orientation of world's sides and to the gains from solar radiation,

- $\mathrm{n}_{50}$ - airtightness of the building casing (table 1 ),

- EU - index of energy demand for heating and ventilation (Table 1).

Due to the confidentiality clause with the owners, the article has given only an indicative location of the buildings.

Table 1. Summary of results and calculations.

\begin{tabular}{|c|c|c|c|c|c|c|c|}
\hline \multirow[t]{2}{*}{ Location } & \multirow[t]{2}{*}{$\begin{array}{c}\text { Symbol } \\
\text { of the } \\
\text { building }\end{array}$} & $\begin{array}{c}\text { Year of } \\
\text { construction }\end{array}$ & $\begin{array}{c}\text { Heated } \\
\text { surface of } \\
\text { the building }\end{array}$ & $\mathbf{A} / \mathbf{V}$ & $\mathbf{U}_{\text {avg. }}$ & $\mathbf{n}_{50}$ & $\mathbf{E U}$ \\
\hline & & {$[-]$} & {$\left[\mathbf{m}^{2}\right]$} & {$\left[\mathrm{m}^{-1}\right]$} & {$\left[\mathbf{W} /\left(\mathbf{m}^{2} \cdot \mathbf{K}\right)\right]$} & {$\left[\mathrm{h}^{-1}\right]$} & {$\left[\mathrm{kWh} /\left(\mathrm{m}^{2} \cdot \mathrm{a}\right)\right]$} \\
\hline Czestochowa & $\mathrm{C}$ & 2013 & 101 & 0,8 & 0,23 & 3,29 & 75 \\
\hline Gdansk & G & 2015 & 109 & 0,9 & 0,10 & 3,04 & 28 \\
\hline Kluczbork & K & 2013 & 140 & 0,7 & 0,15 & 0,17 & 11 \\
\hline \multirow{3}{*}{ Lublin } & L1 & 2011 & 135 & 0,9 & 0,23 & 2,53 & 61 \\
\hline & L2 & 2012 & 95 & 1,0 & 0,15 & 1,95 & 47 \\
\hline & L3 & 2010 & 125 & 0,9 & 0,20 & 3,58 & 55 \\
\hline Olsztyn & $\mathrm{O}$ & 2012 & 198 & 0,7 & 0,23 & 1,58 & 45 \\
\hline Poznan & Po & 2015 & 125 & 0,7 & 0,16 & 0,55 & 15 \\
\hline $\begin{array}{l}\text { Strzelce } \\
\text { Opolskie }\end{array}$ & SO & 2011 & 130 & 0,9 & 0,14 & 1,51 & 23 \\
\hline \multirow{2}{*}{$\begin{array}{c}\text { Tarnowskie } \\
\text { Gory }\end{array}$} & TG1 & 2012 & 145 & 0,7 & 0,19 & 4,02 & 49 \\
\hline & TG2 & 2012 & 145 & 0,7 & 0,20 & 3,62 & 40 \\
\hline \multirow{5}{*}{ Warszawa } & W1 & 1997 & 113 & 0,7 & 0,42 & 5,33 & 82 \\
\hline & W2 & 2012 & 168 & 1,0 & 0,23 & 4,74 & 73 \\
\hline & W3 & 2010 & 141 & 0,9 & 0,17 & 0,86 & 41 \\
\hline & W4 & 2013 & 133 & 0,8 & 0,29 & 3,55 & 41 \\
\hline & W5 & 2015 & 102 & 0,9 & 0,16 & 0,63 & 34 \\
\hline Wroclaw & $\mathrm{Wr}$ & 2011 & 138 & 0,7 & 0,28 & 3,46 & 70 \\
\hline
\end{tabular}

One of the assumptions of the research was to determine if there is a relationship between the $\mathrm{n}_{50}$ and the building characteristics.

At first, the relationship between the year of commissioning and the airtightness was sought (fig.2). The trend is visible (on the chart marked with a dashed line) between $n_{50}$ and the building's age. Despite the noticeable upward tendency of the $n_{50}$ level (relative to the age of the building), it cannot be considered as reliable. Considering that most of the buildings qualified for the study have been erected over the past 5 years, and the divergence 
of the $\mathrm{n}_{50}$ values for individual facilities in those years is significant, only the trend and not the dependency can be indicated.

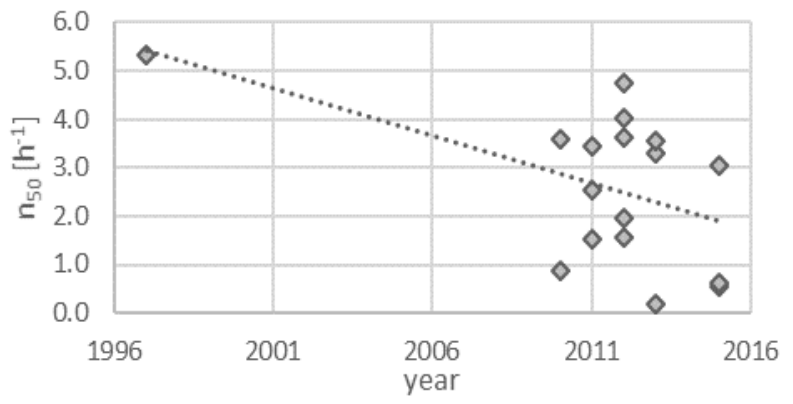

Fig. 2. The dependence of airtightness from buildings construction.

The usable area of buildings designated per the regulations in force [13] is in the range of $95 \mathrm{~m}^{2}$ (for L2 building) and $198 \mathrm{~m}^{2}$ (for building O). The relationship between the airtightness of the building and its usable surface and the surface of the external partitions (Fig.3, Fig.4) is not noticeable. This means that the usable area and the surface of the partitions do not affect the building's leakproof (if the airtightness is expressed with $\mathrm{n}_{50}$ ).

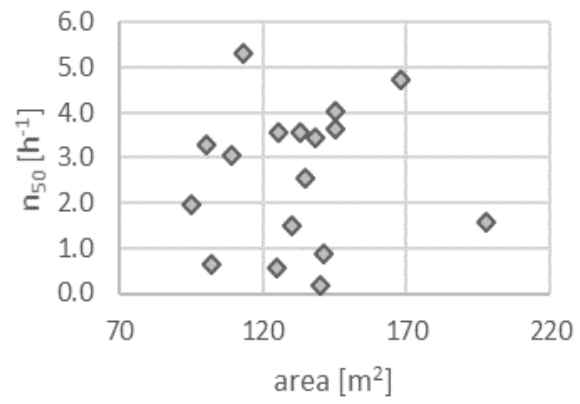

Fig. 3. The dependence of airtightness from floor area of the building.

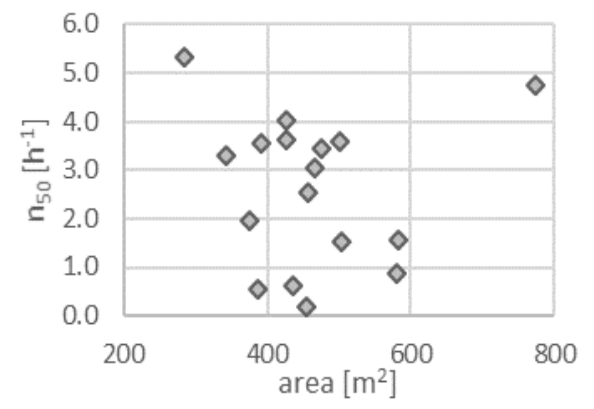

Fig. 4. The dependence of airtightness from the external surfaces of the building.

The comparison of the shape factor $(\mathrm{A} / \mathrm{V})$ of the building with its airtightness does not indicate the existence of a relationship between these two variables (Fig. 5). The chart shows that there were, among others, very compact buildings (low A/V) that were both having low (building W1) and high airtight (building K).

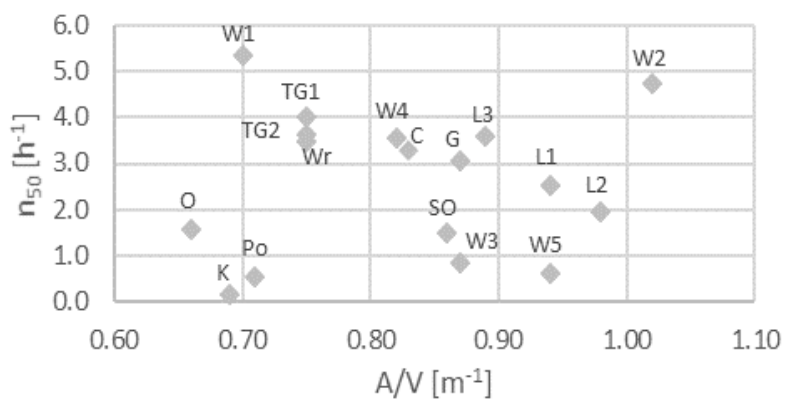

Fig. 5. The dependence of airtightness from A/V. 
The weighted average heat transfer coefficient of all external barrier $\left(\mathrm{U}_{\text {avg. }}\right)$ was chosen for the next set. The graph shows the relationship between the $\mathrm{n}_{50}$ and $\mathrm{U}_{\text {avg. }}$. This means that the high thermal insulation of partitions implies a better airtightness of the building. In energy-efficient construction, the outer partition is usually made as multilayer (due to the requirement of achieving low heat transfer coefficient). For the main premise, for the presence of leaks in energy-saving buildings in Poland, the human factor can be identified. The lack of experienced staff results in sloppy and often improperly airtight coatings [14], for example, in the locations where systems are installed through external barrier [15]. Therefore, the use of laminated materials (when making multi-layered walls) in the bulkhead may lead to involuntary sealing of the building.

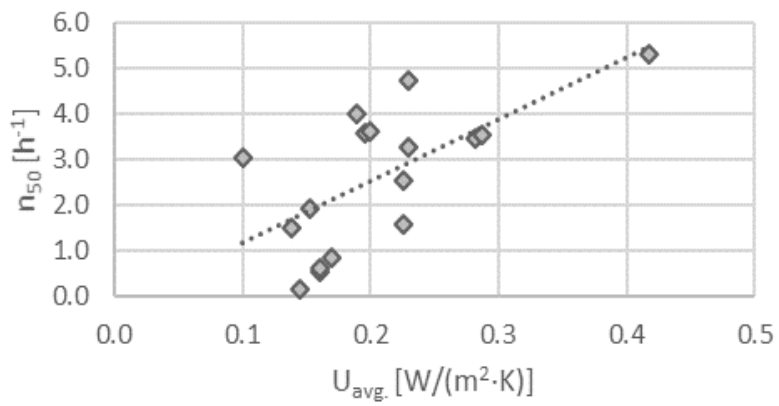

Fig. 6. The dependence of air-tightness from $U_{\text {avg. }}$.

Problems arising from the negligence of the performers, i.e. the mentioned human factor, are difficult to eliminate. For example, if window and door joinery is to be installed, high-precision window-to-wall joints are required. When comparing the window joinery with $\mathrm{n}_{50}$, the trend line (dotted line in Fig. 7) indicates that with the falling of the window surfaces, the value of $n_{50}$ also decreases. This tendency is due to the frequent occurrence of leaks in the place where the joinery connects with the wall. However, there are exceptions from the analysed dependencies (the $\mathrm{W} 1$ building with a high value of $\mathrm{n}_{50}$, despite a small window area of $24 \mathrm{~m}^{2}$, is the extreme case). The reason for this situation is the extremely poorly executed installation of window frames.

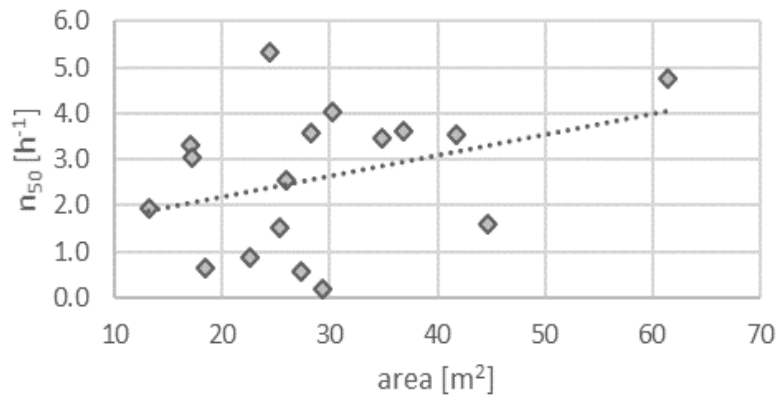

Fig. 7. The dependence of air-tightness from the surface of the windows.

The last parameter analysed was the need for heating and ventilation (EU) for leakage (Fig. 8). The lowest (i.e. the best) value of energy demand was $11 \mathrm{kWh} /\left(\mathrm{m}^{2} \cdot \mathrm{a}\right)$, for a building located in Kluczbork $(\mathrm{K})$. The building was also marked by the best airtightness $\mathrm{n}_{50}=0.17 \mathrm{~h}^{-1}$. The highest EU value was determined for a building in Warsaw (W1) and was $82 \mathrm{kWh} /\left(\mathrm{m}^{2} \cdot \mathrm{a}\right)$, the building also has the highest value of $\mathrm{n}_{50}=5.33 \mathrm{~h}^{-1}$. 


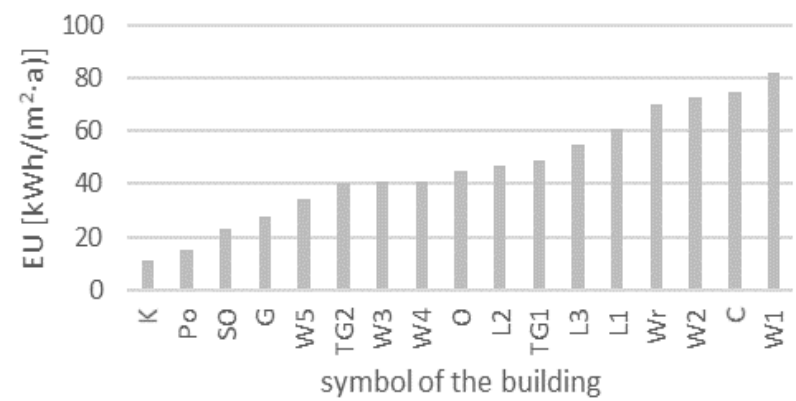

Fig. 8. Building's energy requirements.

After compiling the EU with the $\mathrm{n}_{50}$, the level of infiltration directly translated into the heat demand for heating and ventilation of the tested buildings (Fig. 9).

As the building's airtightness increases (value $\mathrm{n}_{50}$ decrease), the demand for the EU is decreasing (Fig. 9 shows the trend in terms of energy demand for heating and the airtightness of the building's casing).

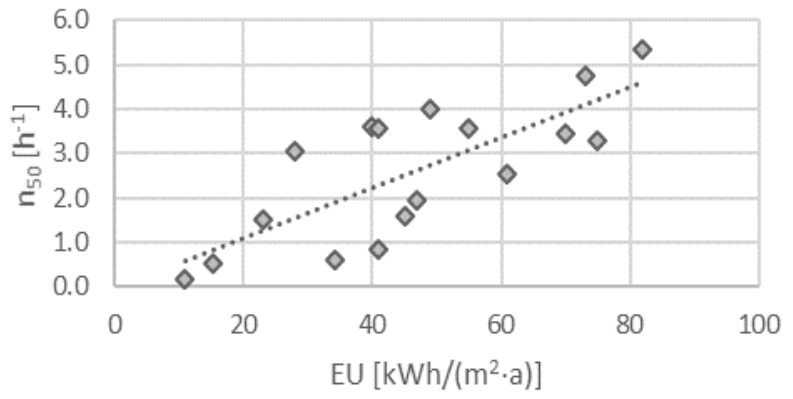

Fig. 9. The dependence of the energy demand of air tightness.

The next stage of the tests, the leakproof of the buildings was simulated. For this purpose, the energy demand for individual buildings has been calculated for the average leakproof of buildings $\left(\mathrm{n}_{50}=2.6 \mathrm{~h}^{-1}\right)$. EU demand calculations for $\mathrm{n}_{50}=1.5 \mathrm{~h}^{-1}$ (recommended value for buildings with mechanical ventilation [1]), $\mathrm{n}_{50}=1.0 \mathrm{~h}^{-1}$ (maximum permissible value for building NF40) and $\mathrm{n}_{50}=0.6 \mathrm{~h}^{-1}$ (maximum permissible value for building NF15 [9]) are also used to check the change in demand.

The average decrease in energy demand for heating and ventilation losses, with a change in leakage from $\mathrm{n}_{50}=2.6 \mathrm{~h}^{-1}$, is respectively:

- for $\mathrm{n}_{50}=1.5 \mathrm{~h}^{-1}-16 \%$,

- for $\mathrm{n}_{50}=1.0 \mathrm{~h}^{-1}-22 \%$, and

- for $\mathrm{n}_{50}=0,6 \mathrm{~h}^{-1}$ is $28 \%$

the decrease in the energy required for heating and ventilation.

\section{Conclusion}

Studies and analyses show that the level of airtightness of a building is influenced by:

a) the length of joinery windows with the wall (and hence the surface of the transparent partitions),

b) heat transfer coefficient through the outer partition,

c) insufficient knowledge of many designers and contractors, as well as inaccuracy and ignorance of the latest trends and solutions. 
Disregarding the leakage test limits the ability to control the work carried out. In addition, the low leakage of the building envelope significantly translates into an increased level of energy demand for heating and ventilation (EU).

In summary, the impact of building tightness on the EU is greater when total energy consumption is lower, so it is important to raise investor, designer and contractor awareness of the relationship between building airtightness and the EU, and strive to eliminate any leaks.

\section{References}

1. Rozporządzenie Ministra Transportu, Budownictwa i Gospodarki Morskiej z dnia 5.VII.2013 zmieniające rozporządzenie w sprawie warunków technicznych, jakim powinny odpowiadać budynki i ich usytuowanie

2. B. Milovanović, I. Banjad Pečur, N. Štirmer, Quality assurance of an energy performance of buildings - airtightness testing (Podgorica Univerzitet Crne Gore, 2012)

3. J. Šadauskienè, V. Paukštys, L. Šeduikyte, K. Banionis, Energies 7(8) (2014)

4. Passive house seminar for professionals from the building sector, Intelligent Energy Europe Project Passnet.

5. K. Nowak, K. Nowak-Dzieszko, Wplyw badań szczelności budynków na ich charakterystykę energetyczna (Wydawnictwa Uczelniane Uniwersytetu Technologiczno-Przyrodniczego w Bydgoszczy, Bydgoszcz, rok???) ISBN 978-8361314-67-7.

6. K. Nowak, K. Nowak-Dzieszko, Materiały Budowlane, 1, 24 (2014)

7. S. Firląg, Czasopismo Techniczne, 109(3-2/B), 105 (2012)

8. PN-EN ISO 9972:2015 Cieplne właściwości użytkowe budynków -- Określanie przepuszczalności powietrznej budynków -- Metoda pomiaru ciśnieniowego z użyciem wentylatora

9. Wytyczne do weryfikacji projektów budynków mieszkalnych, zgodnych ze standardem NFOŚiGW (Warszawa, 2012)

10. A. Miszczuk, Proc. Eng. 153, 461 (2016)

11. PN-EN ISO 13790; „Energetyczne właściwości użytkowe budynków - Obliczanie zużycia energii na potrzeby ogrzewania i chłodzenia"

12. https://www.mir.gov.pl/

13. Rozporządzenie Ministra Transportu, Budownictwa i Gospodarki Morskiej z dnia 25 kwietnia 2012 r. w sprawie szczegółowego zakresu i formy projektu budowlanego.

14. A. Miszczuk, K. H. Żmijewski, Mat. Bud. 1, 24 (2015)

15. S. Firląg, A. Miszczuk, Rynek Instalacyjny 4, 56 (2015) 